\title{
Comparative Study between Homeopathy and Nimesulide on the Prevention of Bone Resorption in Experimental Periodontitis in Rats
} Estudo Comparativo entre Homeopatia e Nimesulida na Prevenção da Reabsorção Óssea em Periodontite Experimental em Ratos

Bruna S. Centurion ${ }^{1}$, Mariana P. Gigliotti ${ }^{1}$, Tiago M. Mergulhão ${ }^{1}$, Thais M. Oliveira ${ }^{2}$, Vivien T. Sakai ${ }^{3}$, Maria A. A. M. Machado ${ }^{2}$, Thiago J. Dionísio ${ }^{4}$, Flávio A. C. Faria ${ }^{5}$, Gustavo P. Garlet ${ }^{5}$, Carlos F. Santos ${ }^{5}$

\begin{abstract}
The aims of this study were to assess the effect of a homeopathic agent (Mercúrios Corrosivos $6 \mathrm{CH}$ ) and a non-steroidal antiinflammatory drug (nimesulide) on the progression of the alveolar bone loss in experimentally induced periodontitis in rats. Sixty (60) Wistar rats were divided into group 1 (homeopathy), group 2 (nimesulide) and group 3 (saline solution). Silk ligatures were placed at the gingival margin level of the lower right first molar of all rats. Alveolar bone loss was evaluated and analyzed using software Image $\mathrm{J}$. The results were submitted to the analysis of variance (ANOVA) and Tukey's posttest $(p<0.05)$. The analysis revealed that there was a higher bone loss in diseased sites as compared with healthy sites. A significant reduction in the alveolar bone resorption was observed in group 2 (nimesulide) as compared with groups 1 (homeopathy) and 3 (control), 7 days after the induction of periodontal disease. Our data provided evidence that homeopathy does not decrease alveolar bone loss as opposed to nimesulide in experimentally induced periodontitis.
\end{abstract}

Keywords: homeopathy, non-steroidal anti-inflammatory, periodontitis, bone resorption, rats.

\section{Introduction}

Inflammatory periodontal disease represents the most important cause of tooth loss in adults (ARMITAGE, 1999; KANTARCI; VAN DYKE, 2005; HORTZ; CONRADS, 2007). Although multifactorial, the pathogenesis of periodontitis involves the presence of a plaque factor that initiates local inflammatory reaction in a predisposed host, thus provoking edema, cell influx, and release of inflammatory mediators. This pathogenesis consists of a cascade of inflammatory and immunological reactions, which have not yet been fully elucidated (CURTIS, 2005; KANTARCI; VAN DYKE, 2005; HORTZ; CONRADS, 2007).

Several studies have demonstrated that cyclooxygenase-2 $(C O X-2)$ is involved in the pathogenesis of periodontitis (OFFENBACHER; HEASMAN; COLLINS, 1993; LOHINAI et al., 2001). In pathophysiological states, such as in inflammatory reactions, triggering of this inducible isoenzyme, induces the production of great amounts of prostaglandins, like prostaglandins E2, which are important mediators in causing tissue destruction and alveolar bone loss in periodontal disease (WILLIANS et al., 1985; JOUZEAU et al., 1997; BEZERRA et al., 2000). Therefore, it has been suggested that therapeutic benefits resulting from classical non-steroidal antiinflammatory drugs (NSAIDs) use are derived from a COX-2 blockade, whereas a concomitant cyclooxygenase-1 (COX-1) blockade by these drugs provokes side effects (NASSAR et al., 2005).

Rev. Fac. Odontol. Porto Alegre, v. 51, n. 2, p. 5-8, mai./ago., 2010.
${ }^{1}$ Graduate Student, Bauru School of Dentistry, University of São Paulo, Bauru/SP, Brazil

${ }^{2}$ Professor, Department of Pediatric Dentistry, Orthodontics and Community Health, Bauru School of Dentistry, University of São Paulo, Bauru/SP, Brazil

${ }^{3}$ Assistant Professor, Department of Clinical and Surgery. Federal University of Alfenas, Brazil

${ }^{4}$ Laboratory technician, Department of Biological Sciences, Bauru School of Dentistry, University of São Paulo, Bauru/SP, Brazil

${ }^{5}$ Professor, Department of Biological Sciences, Bauru School of Dentistry, University of São Paulo, Bauru/SP, Brazil

Correspondência: Prof. Dr. Carlos Ferreira Santos

Endereço: Alameda Dr. Octávio Pinheiro Brisolla, 9-75 - CEP 17012-90, Bauru SP, Brazil

Fone: (14) 3235-8282

E-mail: cebola@usp.br

Data de Submissão: 14/01/2011

Data de Aceite: 06/03/2012

For the dentist who attempt to practice as a physician of the mouth with preventive dental medicine as a part of his/her service, clinical experience has demonstrated that homeopathy can be of benefit. Many homeopathic remedies have been found to be effective for dental conditions, namely dental caries, dental abscess, oral lesions, post-extraction bleeding and even medications to treat the anxious and nervous child (BELLAVITE et al., 2005; BELLAVITE et al., 2006a, 2006b, 2006c; BELLAVITE et al., 2007; BELLAVITE; ORTOLANI; CONFORTI, 2006). The evidence demonstrates that in some conditions homeopathy shows significant promise, e.g. Galphimia glauca (low dilutions/potencies) in allergic oculorhinitis, classical individualized homeopathy in otitis and possibly in asthma and allergic complaints, and a few low-potency homeopathic complexes in sinusitis and rhinoconjunctivitis. A general weakness of evidence derives from lack of independent confirmation of reported trials and from presence of conflicting results, as in case of homeopathic immunotherapy and of classical homeopathy for upper respiratory tract infection (BELLAVITE et al., 2005; BELLAVITE et al., 2006a, 2006b, 2006c; BELLAVITE et al., 2007; BELLAVITE; ORTOLONI; CONFORTI, 2006).

There has been growing public demand for the application of alternative or complementary medicine to some diseases (VAN WASSENHOVEN, 2005; CAULFIELD; DEBOW, 2005; MAXIONBERGEMANN et al., 2006; HAIDVOGL et al., 2007; SCHNEIDER et al., 2008). Conventional scientific wisdom dictates that homeopathy should have no effect above placebo but experiments on ultra-high dilutions of solutes together with some clinical data suggest the intriguing possibility that it might do in some circumstances (BELLAVITE et al., 2006a, 2006b, 2006c; BELLAVITE; ORTOLANI; CONFORTI, 2006). However, the mechanisms of action of these drugs are far from clear, and no previous research aimed at showing the effect of homeopathic treatment on alveolar bone loss in rats. 
Therefore, the aim of this study was to compare and evaluate whether homeopathy and nimesulide, a preferential COX-2 inhibitor, alter alveolar bone loss during the progression of experimentally induced periodontitis in rats.

\section{Materials and Methods}

\section{Animals and induction of periodontal disease}

The Institutional Experimentation Committee for Animal Experiments approved the protocol for this study (protocol \# 01/2006). Sixty (60) male Wistar rats weighing $300 \mathrm{~g}$ were separated into group 1 (Homeopathy - Mercúrios Corrosivos $6 \mathrm{CH}$ (dilution: etílico alcohol $30 \%)$ - for 3 consecutive days, 2 drops every 8 h; 4th - 10th day, 2 drops every $4 h ; 11$ th -30 th day, 2 drops every $2 h ; n=20$ ), group 2 (Nimesulide, $2.83 \mathrm{mg} / \mathrm{kg}$, every 12h, Novaquímica Sigma Pharma Natures Plus, Hortolândia/SP, Brazil; $n=20$ ) and group 3 (Control; 0.1 $\mathrm{mL}$ of $0.9 \%$ saline solution every $12 \mathrm{~h} ; \mathrm{n}=20)$. The experimental periodontitis model in rats was described previously (OLIVEIRA et al., 2008; RODINI et al., 2008). The rats were anesthetized with Tiopental (Thiopentax ${ }^{\circledR}, 60 \mathrm{mg} / \mathrm{kg}$ - intraperitoneally) and received surgically a silk thread ligature around the lower right first molar in a submarginal position to induce experimental periodontitis. The animals were euthanized after 3 and 7 days by excess of anesthetic. The animals were housed in temperature-controlled rooms and received water and food ad libitum.

\section{Measurement of Alveolar Bone Loss}

The left and right maxillary were stained with aqueous methylene blue (1\%) in order to differentiate bone from teeth by an examiner previously trained and calibrated. Bone loss was analyzed using software Image $J$ (The National Institutes of Health - NIH) to measure the distance between the cusp tip and alveolar bone crest. In these conditions, the alveolar bone landmark was determined by methylene blue staining that clearly determines the cemento-enamel junction to the alveolar bone crest. The measurements were made along the long axis of the vestibular root surfaces of all molar teeth. Total alveolar bone loss was obtained by measurements expressed in mm (FERNANDES et al., 2007).

\section{Statistical Analysis}

The statistical significance was assessed by ANOVA, followed by multiple comparisons with Tukey's test. A statistically significant difference was considered if $p<0.05$.

\section{Results}

A clinical macroscopic analysis of the right and left mandibular first molars was performed for each animal, verifying the presence of alveolar bone loss and consequent tooth mobility (Fig 1, upper panel).

The analysis of alveolar bone loss revealed that there was a statistically significant difference in diseased sites as compared with healthy sites (left side without ligature) in all groups and periods studied. A statistically lower level $(p<0.05)$ of alveolar bone loss was observed in group 2 (nimesulide) as compared with groups 1 (homeopathy) $(p=0,0094)$ and 3 (control) $(p=0,0376), 7$ days after the induction of periodontal disease (Fig 1, lower panel).

Double measurements of the alveolar bone loss of 30 specimens were performed within the period of two week by a single, calibrated, blind examiner. A correlation was obtained between the 2 measurements, and verified by intra-class correlation coefficient (ICC $=0.79$ ).

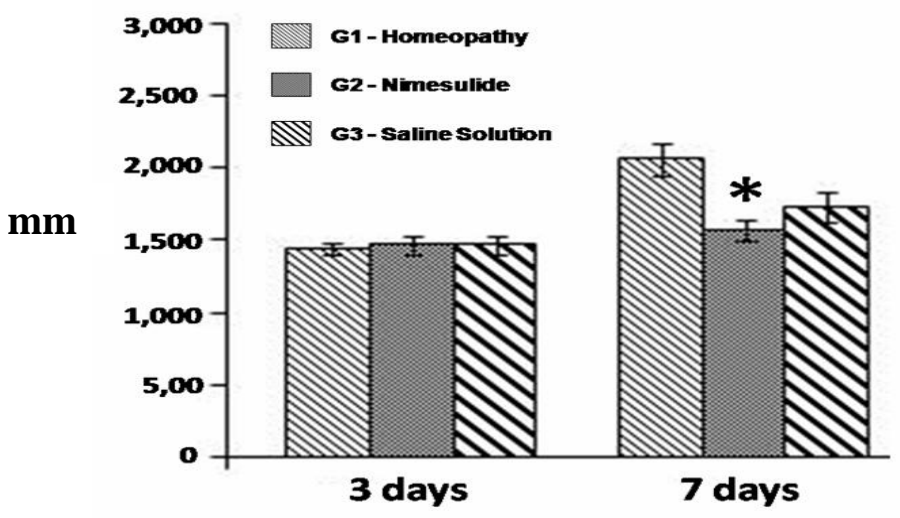

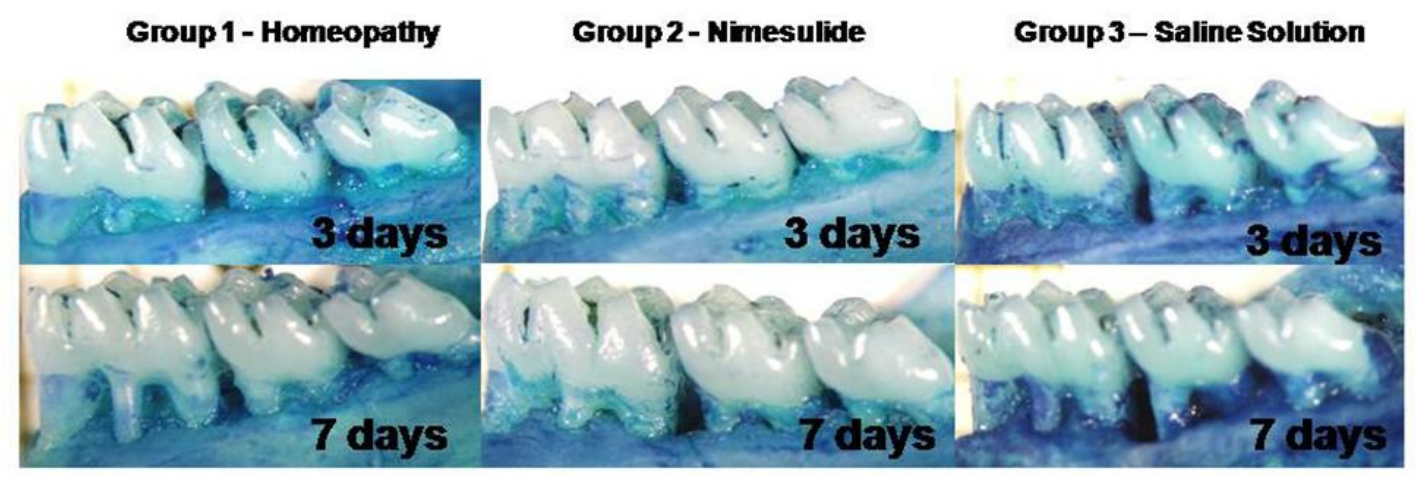

Figure 1 - Illustrative effect of homeopathy, nimesulide and saline solution on the alveolar bone loss in experimentally-induced periodontal disease in rats (upper panel) as well as values expressed as mean \pm standard error of mean (lower panel). ${ }^{*}$ indicates statistically significant difference in comparison with homeopathy $(p<0.05)$.

Rev. Fac. Odontol. Porto Alegre, v. 51, n. 2, p. 5-8, mai./ago., 2010. 


\section{Discussion}

There is evidence that animals treated with various antiinflammatory drugs show less periodontal destruction (WILLIANS et al., 1985; BEZERRA et al., 2000; MORTON et al., 2001; BEZERRA et al., 2002; ALENCAR et al., 2002; LEITÃO et al., 2004; BHAT; SARGOD; GEORGE, 2005; OLIVEIRA et al., 2008). Rats have been extensively used to study the effects of these drugs in the periodontium. In the present study, the rat model of periodontitis, which comprises a ligature around the tooth, was utilized (OFFENBACHER; HEASMAN; COLLINS, 1993; JOUZEAU et al., 1997; KHUDA-BUKHSH, 2003; BHAT; SARGOD; GEORGE, 2005; RODINI et al., 2008; OLIVEIRA et al., 2008). This model is characterized by accumulation of biofilm, flattening and displacement of the gingival crest, increasing of the number of bacteria on the dentogingival area and alveolar bone loss (OFFENBACHER; HEASMAN; COLLINS, 1993). Thus, it may be considered an acceptable model for the study of periodontal disease.

In the present study, we studied the effect of a homeopathic agent (Mercúrios Corrosivos $6 \mathrm{CH}$ ) and a non-steroidal antiinflammatory drug (nimesulide) on the alveolar bone loss progression in experimentally induced periodontitis in rats. Non-steroidal antiinflammatory drugs can be given for pain, but these drugs are not always tolerated. There is an increasing trend among physicians and dentists in many countries, towards the use of complementary and alternative medicine (CAM) in addition to, and in some cases instead of conventional medicine (JONAS ; KAPTCHUK; LINDE, 2003; SCHNEIDER et al., 2008). Growing popularity of CAM in the public sector is reflected in the scientific community by an increased number of research articles assessing its therapeutic effects. Homeopathy is one of the most widespread and most controversial forms of CAM (CAULFIELD; DEBOW, 2005; WITT et al., 2005; KEIL et al., 2008). Results suggest lower costs for CAM than for conventional patients, but the limited methodological quality lowers the significance of the available data. Further well-designed studies and models are required (WITT et al., 2005; MAXION-BERGEMANN et al., 2006; KEIL et al., 2008).

This study revealed that the groups treated with nimesulide and homeopathy showed significant difference at 7 days after the induction of periodontal disease. The administration of nimesulide prevented the onset of significant bone loss at 7 days after induction of periodontal disease when compared with homeopathy and control. Nimesulide is a non-steroidal anti-inflammatory drug (NSAID) that preferentially inhibits COX-2, and is not only a potent inhibitor of acute exudation but also an intense inhibitor of bone destruction. Other works confirmed that the COX-2 preferential inhibitors can be effective in preventing alveolar bone loss in experimental periodontitis in rats (JOUZEAU et al., 1997; MORTON et al., 2001; BEZERRA et al., 2002; ALENCAR et al., 2002; OLIVEIRA et al., 2008).

Based on the findings of the present study and due to the current lack of evidence-based homeopathic treatment for periodontal diseases, the homeopathy cannot considered a possible effective alternative for periodontitis. The current situation is that few and rather small groups are working on laboratory models for homeopathy. Regarding the interpretation of data in view of the simile principle, we observe that there are different levels of similarity and that the laboratory data give support to this principle, but have not yet yielded the ultimate answer to the action mechanism of homeopathy. Evidence of the biological activity in vitro of highly diluted-dynamized solutions is slowly accumulating, with some conflicting reports (BELLAVITE et al., 2005; BELLAVITE et al., 2006a, 2006b, 2006c; BELLAVITE et al., 2007; BELLAVITE; ORTOLONI; CONFORTI, 2006). While clinical effects of some homeopathic drugs could be convincingly shown, one of the greatest objections to this modality lies in its inability to explain the mechanism of action of the microdoses based on scientific experimentations and proofs.

Though many aspects of the mechanism of action still remain unclear, serious efforts have now been made to understand the molecular mechanisms of biological responses to the potentized form of homeopathic drugs (JONAS; KAPTCHUK; LINDE, 2003; SCHNEIDER et al., 2005; BELLAVITE et al., 2005; BELLAVITE et al., 2006a, 2006b, 2006c; BELLAVITE et al., 2007; BELLAVITE; ORTOLONI; CONFORTI, 2006; SCHNEIDER et al., 2008). Many other questions should be prioritized, such as the potential of homeopathy to avoid invasive procedures and the long-term effects of homeopathy in preventing chronic complications (VAN WASSENHOVEN et al., 2005; OBERBAUM et al., 2005). Further studies should be performed to explore the various aspects that are not yet elucidated.

\section{Conclusion}

Our data provided evidence that the systemic therapy with COX-2 preferential inhibitors can modify the progression of periodontitis by decreasing alveolar bone loss and that homeopathy may not be considered a promising agent in the treatment of periodontal disease.

\section{References}

ALENCAR, V.B.M. et al. Disodium chlodronate prevents bone resorption in experimental periodontitis in rats. J. Periodontol., Chicago, v. 73, no. 3, p. 251-256, Mar. 2002.

ARMITAGE, G.C. Development of a classification system for periodontal diseases and conditions. Ann. Periodontol., Chicago, v. 4, no.1, p.1-6, Dec. 1999

BHAT, S.S.; SARGOD, S.S.; GEORGE, D. Dentistry and homeopathy: an overview. Dent. Update, Guildford, v. 32, no. 8, p. 486-488, 491, Oct. 2005.

BELLAVITE, P. et al. Immunology and homeopathy. 1. Historical background. Evid. Based Complement. Alternat. Med., Oxford, v. 2, no. 4, p. 441-452, Dec. 2005.

BELLAVITE, P. et al. Immunology and homeopathy. 2. Cells of the immune system and inflammation. Evid. Based Complement. Alternat. Med., Oxford, v. 3, no. 1, p.13-24, Mar. 2006a.

BELLAVITE, P. et al. Immunology and homeopathy. Clinical studiespart 1. Evid. Based Complement. Alternat. Med., Oxford, v. 3, no. 3, p. 293-301, 2006b.

BELLAVITE, P. et al. Immunology and homeopathy. 4. Clinical studies-part 2. Evid. Based Complement. Alternat. Med., Oxford, v. 3, no. 4, p. 397-409, Dec. 2006c.

BELLAVITE, P. et al. Immunology and homeopathy. 5. The Rationale of the 'Simile'. Evid. Based Complement. Alternat. Med., Oxford, v. 4, no.2, p.149-163, June 2007.

BELLAVITE, P.; ORTOLANI, R.; CONFORTI, A. Immunology and homeopathy. 3. Experimental studies on animal models. Evid. Based Complement. Alternat. Med., Oxford, v. 3, no. 2, p.171-186, June 2006. 
BEZERRA, M.M. et al. Low-dose doxycyxline prevents inflammatory bone resorption in rats. Braz. J. Med. Biol. Res., São Paulo, v. 35, no. 5, p. 613-616, May 2002.

BEZERRA, M.M. et al. Selective cycloxygenase-2 inhibition prevents alveolar bone loss in experimental periodontitis in rats. $\mathbf{J}$. Periodontol., Chicago, v. 71, no. 6, p.1009-1014, June 2000.

CAULFIELD, T.; DEBOW, S. A systematic review of how homeopathy is represented in conventional and CAM peer reviewed journals. BMC Complement. Altern. Med., London, v. 5, p. 12, June 2005.

CURTIS, E.K. Inflammatory response. J. Mass. Dent. Soc., Boston, v. 54 , no. 3 , p. 48 , Fall 2005.

FERNANDES, M.I. et al. Comparison of histometric and morphometric analyses of bone height in ligature-induced periodontitis in rats. Braz. Oral Res., São Paulo, v. 21, no. 3, p. 216-221, July/Sept. 2007.

HAIDVOGL, M. et al. Homeopathic and conventional treatment for acute respiratory and ear complaints: a comparative study on outcome in the primary care setting. BMC Complement. Altern. Med., London, v. 7, p. 7, Mar. 2007.

HORZ, H.P.; CONRADS, G. Diagnosis and anti-infective therapy of periodontitis. Expert Rev. Anti Infect. Ther., London, v. 5, no. 4, p. 703-715, Aug. 2007.

JONAS, W.B.; KAPTCHUK, T.J.; LINDE, K. A critical overview of homeopathy. Ann. Intern. Med., United States, v. 138, no. 5, p. 393399, Mar. 2003.

JOUZEAU, J.Y. et al. Cyclo-oxygenase isoenzymes. How recent findings affect thinking about nonsteroidal anti-inflammatory drugs. Drugs, New York, v. 53, no. 4, p. 563-582, Apr. 1997.

KANTARCI, A.; VAN DYKE, T.E. Resolution of inflammation in periodontitis. J. Periodontol., Chicago, v. 76, Suppl. 11, p. 21682174, Nov. 2005.

KEIL, T. et al. Homoeopathic versus conventional treatment of children with eczema: a comparative cohort study. Complement. Ther. Med., Edinburgh, v.16, no.1, p.15-21, Feb. 2008.

KHUDA-BUKHSH, A.R. Towards understanding molecular mechanisms of action of homeopathic drugs: an overview. Mol. Cell Biochem., The Hague, Netherlands, v. 253, no.1-2, p. 339-345, Nov. 2003.

LEITÃO, R.F.C. Locally applied isosorbite decreases bone resorption in experimental periodontitis in rats. J. Periodontol., Chicago, v. 75, no. 9, p. 1225-1230, Sept. 2004.

LOHINAI, Z. Evidence for the expression of cyclooxygenase-2 enzyme in periodontitis. Life Sci., Oxford, v. 70, no. 3, p. 279-290, Dec. 2001.

MAXION-BERGEMANN, S. Complementary and alternative medicine costs - a systematic literature review. Forsch. Komplementmed., Basel, Switzerland, v. 13, Suppl. 2, p. 42-45, 2006.

MORTON, R.S.; DONGARI-BAGTZOGLOU, A.I. Cyclooxygenase-2 is upregulated in inflamed gingival tissues. Life Sci., Oxford, v. 72, no. 4, p. 461-469, Apr. 2001.
NASSAR, C.A. et al. Selective cyclooxygenase-2 inhibition prevents bone resorption. Braz. Oral Res., São Paulo, v. 19, no. 1, p. 36-40, Jan./Mar. 2005.

OBERBAUM, M. Homeopathy in emergency medicine. Wien. Med. Wochenschr., Wien, Austria, v.155, no. 21-22, p. 491-497, Nov. 2005.

OFFENBACHER, S.; HEASMAN, P.A.; COLLINS, J.G. Modulation of host PGE2 secretion as a determinant of periodontal disease expression. J. Periodontol., Chicago, v. 64, Suppl. 5, p. 432-444, May 1993.

OLIVEIRA, T.M. COX-2 inhibition decreases VEGF expression and alveolar bone loss during the progression of experimental periodontitis in rats. J. Periodontol., Chicago, v. 79, no. 6, p.1062-1069, June 2008.

RODINI, C.O. et al. Morphologic evaluation and expression of matrix metalloproteinases-2 and 9 and nitric oxide during experimental periodontal disease in rat. J. Mol. Histol., Dordrecht, v. 39, no. 3, p. 275-282, June 2008.

SCHNEIDER, C. A homeopathic ointment preparation compared with $1 \%$ diclofenac gel for acute symptomatic treatment of tendinopathy. Explore (NY), New York, v. 1, no. 6, p. 446-452, Nov. 2005.

SCHNEIDER, C. The role of a homoeopathic preparation compared with conventional therapy in the treatment of injuries: an observational cohort study. Complement. Ther. Med., Edinburgh, v. 16, no. 1, p. 22-27, Feb. 2008.

VAN WASSENHOVEN, M. Priorities and methods for developing the evidence profile of homeopathy. Recommendations of the $\mathrm{ECH}$ general assembly and XVIII Symposium of GIRI. Homeopathy, Edinburgh, v. 94, no. 2, p.107-124, Aug. 2005.

WILLIAMS, R.C. Flurbiprofen: a potent inhibitor of alveolar bone resorption in beagles. Science, New York, v. 227 , no. 4687 , p. $640-$ 642, June 1985.

WITT, C. Outcome and costs of homeopathic and conventional treatment strategies: a comparative cohort study in patients with chronic disorders. Complement. Ther. Med., Edinburgh, v. 13, no. 2, p. 79-86, June 2005. 